\title{
Polymorphisms of paraoxonase 1 and 2 genes and the risk of multiple sclerosis in the Polish population
}

\section{Polimorfizmy genów paraoksonazy 1 oraz 2 jako czynnik ryzyka rozwoju stwardnienia rozsianego w populacii polskiej}

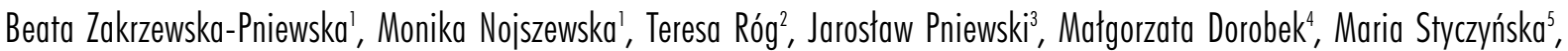
Andrzej Szczudlik

\author{
IKatedra i Klinika Neurologii, Warszawski Uniwersytet Medyczny \\ ${ }^{2}$ Katedra i Klinika Neurologii Collegium Medicum, Uniwersytet Jagielloński w Krakowie \\ ${ }^{3}$ Klinika Neurologii, Szpital Czerniakowski w Warszawie \\ ${ }^{4}$ Klinika Neurologii, CSK MSW w Warszawie \\ 5Zespół Badawczo-Leczniczy Chorób Zwyrodnieniowych CUN, Instyłtut Medycyny Doświadczalnej i Klinicznej im. M. Mossakowskiego PAN w Warszawie
}

Neurologia i Neurochirurgia Polska 2013; 47, 1: 49-52

DOl: 10.5114/ninp.2013.32935

\begin{abstract}
Background and purpose: The aim of this study was to test the hypothesis that polymorphisms of the paraoxonase genes PON1 and PON2 may be associated with increased risk of developing multiple sclerosis (MS) in the Polish population. Material and methods: We studied the significance of the PON gene polymorphisms C311S, A162G, Q192R and L5 $5 \mathrm{M}$ in 221 patients (including 145 women) with MS and in 661 healthy controls. In the MS population, mean Expanded Disability Status Scale score was 2.92, mean age was 36.8 years, and mean disease duration was 7.7 years. $P O N$ genotyping was determined using polymerase chain reaction and restriction enzyme digestion.
\end{abstract}

Results: According to our results, the PON1 and PON2 genotypes distribution did not differ between the MS patients and the controls.

Conclusions: The polymorphisms of the PON genes studied are not related to increased risk of MS in the Polish population.

Key words: multiple sclerosis, PON1, PON2, polymorphism.

\section{Streszczenie}

Wstęp i cel pracy: Celem pracy było zweryfikowanie hipotezy, że polimorfizm genów PON1 i PON2 może być związany $\mathrm{z}$ ryzykiem wystąpienia stwardnienia rozsianego $(\mathrm{SR}) \mathrm{w}$ populacji polskiej.

Materiał i metody: Autorzy badali znaczenie polimorfizmu genów PON: C311S, A162G, Q192R oraz L55M, u 221 chorych na SR (w tym 145 kobiet) oraz u 661 zdrowych osób z grupy kontrolnej. W grupie chorych na SR średnia punktacja w Expanded Disability Status Scale (EDSS) wynosiła 2,92 pkt, średnia wieku - 36,8 roku, a średni czas trwania choroby 7,7 roku. Polimorfizm -A162G genu PON1 badano za pomoca reakcji łańcuchowej polimerazy (PCR) z analizą ilości produktu w czasie rzeczywistym, a pozostałe polimorfizmy za pomoca PCR i trawienia odpowiednimi enzymami restrykcyjnymi.

Wyniki: Nie stwierdzono istotnych statystycznie różnic w rozkładzie genotypów PON1 i PON2 pomiędzy grupą chorych a grupą kontrolną.

Wnioski: Wyniki pracy nie wskazują, aby istniała zależność pomiędzy polimorfizmem genów $P O N 1$ oraz PON2 a zwiększonym ryzykiem wystąpienia SR w populacji polskiej.

Słowa kluczowe: stwardnienie rozsiane, $P O N 1, P O N 2$, polimorfizm.

Correspondence address: Dr hab. Beata Zakrzewska-Pniewska, Katedra i Klinika Neurologii, Warszawski Uniwersytet Medyczny, ul. Banacha 1A, 02-097 Warszawa, Polska, phone: + 482259928 90, fax: + 482259912 57, e-mail: beata.zakrzewska-pniewska@wum.edu.pl

Received: 22.08.2012; accepted: 2.11.2012 


\section{Introduction}

Multiple sclerosis (MS) is a chronic degenerative disease of the central nervous system (CNS) that is characterised by inflammation, myelin loss, oligodendrocyte depletion, gliosis and axonal pathology. The aetiology of MS is not known, but includes both genetic and environmental factors [1]. Increasing evidence supports the role of oxidative stress and free radicals in the pathogenesis of MS. The CNS is characterised by high oxygen consumption as well as a high level of polyunsaturated fatty acid (PUFA), making it especially vulnerable to lipid peroxidation. Increased lipid peroxide levels have been reported in the cerebrospinal fluid (CSF) and in the blood of MS patients [2].

High density lipoproteins (HDL) are involved in the antioxidant effect against lipid peroxidation induced by free radicals. The protective effect of HDL against lipid peroxidation seems to be related to HDL surface proteins - paraoxonases (PON). Paraoxonase-1 (PON1) is encoded by the gene PON1 on chromosome 7q21.3 and is expressed in a variety of tissues but is mainly synthesized by the liver $[3,4]$. PON 1 is a calcium-dependent esterase first described for its capacity to hydrolyse organophosphates but now considered more important for its antioxidative and anti-inflammatory properties such as low-density lipoprotein (LDL) protection against oxidative stress, reduction of macrophage foam cell formation and prevention of atherosclerosis development [4]. The high variability in PON1 activity has been attributed to gene polymorphism, which has been associated with various diseases: coronary heart disease, Parkinson disease or diabetes mellitus type 2 (for review see [4]). There are two major PON1 gene polymorphisms, Q192R and L55M, which independently modify activity of plasma paraoxonase. Alleles $\mathrm{R}$ and $\mathrm{L}$ of PON1 are associated with decreased ability of the enzyme to protect LDL against oxidation [4].

Next to the PON1 gene on chromosome 7 is the locus for PON2, whose mRNA has been detected in almost every human tissue but whose product and function are still not fully known. PON2 is not present in HDL particles in the circulation. It has been suggested that PON2 is responsible for reduction of oxidative stress and protection against atherosclerosis [3]. PON2 gene polymorphism has been described in a number of disorders: cardiovascular, diabetes mellitus type 2 and inflammatory bowel diseases (for review see [4]). An example may be allele $\mathrm{C}$ of $P O N 2$, which causes lower ability to protect $\mathrm{LDL}$ as compared to allele $\mathrm{S}$ [3].
The decreased antioxidative activity of paraoxonase, seen in carriers of $P O N 1$ alleles $\mathrm{R}$ and $\mathrm{L}$, as well as weakening of the local antioxidant mechanisms in PON2 allele $\mathrm{C}$ carriers may be associated with an increased risk of developing MS. To identify genetic factors of increasing MS risk, we mapped the most common polymorphisms of genes PON1 and PON2 (C311S, A162G, Q192R and L55M) in Polish patients with MS and in healthy controls.

\section{Material and methods}

We studied 221 unrelated patients with clinically definite MS diagnosed according to the McDonald criteria [5] from MS Units in Departments of Neurology from Krakow and Warsaw (145 women and 76 men; mean age $36.8 \pm 10.5 \mathrm{yrs}$; mean disease duration $7.70 \pm 6.8 \mathrm{yrs}$; mean disease onset $28.8 \pm 9.1 \mathrm{yrs}$, mean Expanded Disability Status Scale [EDSS] score $2.92 \pm 2.0$ points). The course of MS was relapsing-remitting (RR) in 155 patients $(70.14 \%)$, progressive-relapsing $(\mathrm{RP})$ in $22(9.95 \%)$, primary progressive (PP) in $2(0.91 \%)$ and secondary progressive (SP) in 42 (9.95\%). We compared the results with the control group $(n=661 ; 335$ women; mean age $55.3 \pm 17.3 \mathrm{yrs})$. MS patients were significantly younger than the controls $(p<0.01)$ and the gender distribution was unequal (65.5\% women in MS group vs. $55.7 \%$ in control group) $(p<0.002)$. All control subjects had no history of previous neurological diseases and were examined by neurologists to exclude neurological disorders. Both patients and controls were of Caucasian origin and Polish descent. All participants gave informed consent prior to inclusion in the study. The protocol was reviewed and approved by the Ethics Committee of the Jagiellonian University in Krakow.

\section{DNA analyses}

The PON1 Q192R (rs 662), L55M (rs 854560), $161 \mathrm{C} / \mathrm{T}$ (rs 705381) and PON2 C311S (rs 6954345) polymorphisms were studied. DNA was extracted from leucocytes using a commercially available kit (Boehringer Mannheim, Germany).

The individual genotypes for the PON1 Q192R and PON1 L55M single nucleotide polymorphisms (SNPs) were determined using the polymerase chain reaction restriction fragment length polymorphism method [6]. The PON2 C311S genotyping was determined using polymerase chain reaction and restriction enzyme digestion [7]. 
Genotyping of the $-161 \mathrm{C} / \mathrm{T}$ PON1 polymorphism was performed on an ABI PRISM ${ }^{\circledR} 7900$ HT Fast Real-Time PCR System (Applied Biosystems) using TaqMan Universal PCR Master Mix (Applied Biosystems) as described elsewhere [8].

\section{Statistical analyses}

The genotype and allele frequencies of the PON SNPs were compared between cases and controls using the $\chi^{2}$ test (SAS Genetics 9.1). The Hardy-Weinberg equilibrium was verified for all polymorphisms in the tested population. Adjusted odds ratios (OR) with $95 \%$ confidence intervals (CI) were estimated by logistic regression, controlling for age and gender. Because four different polymorphisms were assessed, the Bonferroni correction was applied and the level of significance was set at $p<0.01$.

\section{Results}

The genotypes and allele frequencies were in HardyWeinberg equilibrium for both groups. Genotypes and allele frequencies did not differ significantly between MS patients and the control group and were not influenced by gender and age (Table 1).

\section{Discussion}

Until now only a few studies have been conducted considering the role of oxidative stress, especially lipid oxidation, in the pathogenesis of MS. Newcombe et al. [9] reported the presence of oxidated LDL and lipid oxidation products in early and active demyelinating plaques in brain biopsy specimens from MS patients. Besler et al. [10] reported a significantly higher index of plasma oxidation, higher anti-oxLDL antibody level as well as marked decrease of plasma antioxidative activity in MS patients in comparison to healthy controls. The presence of oxidative damage to proteins, lipids and nucleotides as well as marked upregulation of antioxidant enzymes has also been shown in active demyelinating lesions (for review see [2]). Ferreti $e t$ al. [11] reported that MS patients in the early stage of disability (EDSS < 3.5) have lower activity of plasma

Table 1. Distribution of genotypes of PON1 and PON2 gene polymorphisms in Polish multiple sclerosis (MS) patients and in control group

\begin{tabular}{|c|c|c|c|c|c|c|}
\hline & & & $\begin{array}{l}\text { MS patients } \\
(n=221)\end{array}$ & $\begin{array}{l}\text { Control group } \\
(n=661)\end{array}$ & p-value & $p$-value \\
\hline \multirow[t]{12}{*}{ PON1 } & \multirow[t]{4}{*}{ Q192R } & Genotypes & & & & \\
\hline & & QQ & $112(50.7 \%)$ & $364(55.1 \%)$ & $0.26^{*}$ & $0.19 * *$ \\
\hline & & QR & $95(43.0 \%)$ & $253(38.1 \%)$ & $0.87^{\#}$ & $0.81^{\# \#}$ \\
\hline & & $\mathrm{RR}$ & $14(6.3 \%)$ & $44(6.65 \%)$ & $0.396^{\S}$ & $0.25 \S \S$ \\
\hline & \multirow[t]{4}{*}{$\mathrm{L} 55 \mathrm{M}$} & Genotypes & & & & \\
\hline & & LL & $96(43.4 \%)$ & $274(41.5 \%)$ & $0.60 *$ & $0.39 * *$ \\
\hline & & LM & $100(45.3 \%)$ & $320(48.4 \%)$ & $0.62^{\#}$ & $0.87^{\# \#}$ \\
\hline & & MM & $25(11.3 \%)$ & $67(10.1 \%)$ & $0.87 \S$ & $0.47 \S \S$ \\
\hline & \multirow[t]{4}{*}{ A162G } & Genotypes & & & & \\
\hline & & GG & $117(52.9 \%)$ & $372(56.3 \%)$ & $0.39 *$ & $0.53 * *$ \\
\hline & & GA & $92(41.6 \%)$ & $250(37.8 \%)$ & $0.82^{\#}$ & $0.51^{\# \#}$ \\
\hline & & AA & $12(5.4 \%)$ & $39(5.9 \%)$ & $0.54 \S$ & $0.44 \S \S$ \\
\hline \multirow[t]{4}{*}{ PON2 } & \multirow[t]{4}{*}{$\mathrm{C} 311 \mathrm{~S}$} & Genotypes & & & & \\
\hline & & SS & $131(59.3 \%)$ & $392(59.3 \%)$ & $0.99 *$ & $0.91 * *$ \\
\hline & & SC & $76(34.4 \%)$ & $226(34.2 \%)$ & $0.93^{\#}$ & $0.47^{\# \#}$ \\
\hline & & $\mathrm{CC}$ & $14(6.3 \%)$ & $43(6.5 \%)$ & $0.98 \S$ & $0.71 \S \S$ \\
\hline
\end{tabular}

¿dominant model $(R R+Q R$ vs. $Q Q)$; logistic regression analysis

"dominant model ( $R R+Q R$ vs. QQ); logistic regression analysis after adjustment for age and sex

"recessive model $(Q Q+Q R$ vs. $R R) ;$ logistic regression analysis

\#"recessive model $(Q Q+Q R$ vs. $R R)$; logistic regression analysis after adjustment for age and sex

sadditive model (RR vs. $Q R$ vs. $Q Q$ ); the Cochran-Armitage trend test

${ }^{s s}$ additive model (RR vs. $Q R$ vs. $Q Q$ ) after adjustment for age and gender (the Cochran-Armitage trend test) 
paraoxonase and about 5 -fold higher level of cholesteryl ester hydroperoxides (CE-OOH) (marker of lipid peroxidation) as compared to healthy controls. In another study published in 2006 [12], they suggested increased spontaneous intracellular production of free radicals in leucocytes of MS patients compared to healthy controls. Moreover, Ferreti et al. [12] found a positive correlation between increased free radical production and EDSS score, magnetic resonance imaging changes and visual evoked potential results. Sidoti et al. [13] reported increased risk of developing MS among Italian patients with PON55/LM-MM genotype compared with other genotypes. However, the results of a study by Martinez et al. [14] were controversial. They found that the frequencies of the PON1 genotypes and allelic variants did not differ between MS patients and healthy controls in the Spanish Caucasian population and were unrelated to gender, age of onset and MS course.

In our study, we did not find any significant differences in the PON1 (Q192R, L55M, A162G) and $P O N 2$ C311S genotypes and allele distribution between Polish patients with MS and the control group.

Our study has some obvious limitations. MS patients and controls were not sex-matched. This is mainly due to the fact of higher prevalence of MS among women (with a female to male ratio of $2: 1$ ), while the control group was population based. The stratified analysis by gender showed no differences between females and males and therefore the lack of gender matching seemed to be irrelevant. Our MS group was also significantly younger than the controls, but statistical stratified analysis showed no influence of age.

\section{Conclusion}

The results of the present study suggest that PON1 and PON2 polymorphisms are not a risk factor of developing MS in the Polish population.

\section{Disclosure}

The study was supported by educational grant $1 \mathrm{WC} /$ W2/08-09 from the Medical University of Warsaw.

The authors report no conflict of interest.

\section{References}

1. Compston A., Coles A. Multiple sclerosis. Lancet 2008; 372: 1502-1517.

2. van Horssen J., Witte M.E., Schreibelt G., et al. Radical changes in multiple sclerosis pathogenesis. Biochim Biophys Acta 2011; 1812: 141-150.

3. Li H.L., Liu D.P., Liang C.C. Paroxonase gene polymorphisms, oxidative stress, and diseases. J Mol Med 2003; 81: 766-779.

4. Percourt L.-P., Amre D., Denis M.-C., et al. The three-gene paroxonase family: physiologic roles, actions and regulation. Atherosclerosis 2011; 214: 20-36.

5. McDonald W.I., Compston A., Eddan G., et al. Recommended diagnostic criteria for multiple sclerosis: guidelines from the International Panel on the diagnosis of multiple sclerosis. Ann Neurol 2005; 50: 121-127.

6. Ombres D., Pannitteri G., Montali A., et al. The Gln-Arg192 polymorphism of human paraoxonase gene is not associated with coronary artery disease in Italian patients. Arterioscler Thromb Vasc Biol 1998; 18: 1611-1616.

7. Mackness B., Durrington P.N., Abuashia B., et al. Low paraoxonase activity in type II diabetes mellitus complicated by retinopathy. Clin Sci (Lond) 2000; 98: 355-363.

8. Zawiślak D., Ostrowska M., Golenia A., et al. The -A162G polymorphism of the PON1 gene and the risk of sporadic amyotrophic lateral sclerosis. Neurol Neurochir Pol 2010; 44: 246-250.

9. Newcombe J., Li H., Cuzner M.L. Low density lipoprotein uptake by microphages in multiple sclerosis plaques: implications for pathogenesis. Neuropathol Appl Neurobiol 1994; 20: 152-162.

10. Besler H.T., Comoğlu S. Lipoprotein oxidation, plasma total antioxidant capacity and homocysteine level in patients with multiple sclerosis. Nutr Neurosci 2003; 6: 189-196.

11. Ferretti G., Bacchetti T., Principi F., et al. Increased levels of lipid hydroperoxides in plasma of patients with multiple sclerosis: a relationship with paroxonase activity. Mult Scler 2005; 11: 677-682.

12. Ferretti G., Bacchetti T., DiLudovico F., et al. Intracellular oxidative activity and respiratory burst of leukocytes isolated from multiple sclerosis patients. Neurochem Int 2006; 48: 87-92.

13. Sidoti A., Antognelli C., Rinaldi C., et al. Glyoxalase I A111E, paroxonase 1 Q192R and L55M polymorphisms: susceptibility factors of multiple sclerosis? Mult Scler 2007; 13: 446-453.

14. Martinez C., Garcia-Martin E., Benito-Leon J., et al. Paraoxonase 1 polymorphysms are no related with the risk for multiple sclerosis. Neuromol Med 2010; 12: 217-223. 